\title{
Gambaran Perilaku Hygiene Menstruasi pada Siswi SMKN 8 Kota Bekasi
}

\author{
Noor Latifah A
}

Program Studi Kesehatan Masyrakat Fakultas Kedokteran dan kesehatan Universitas Muhammadiyah Jakarta

\begin{abstract}
Abstrak
Kesehatan reproduksi dikalangan remaja merupakan masalah yang sangat penting untuk mendapatkan perhatian. Upaya untuk menuju reproduksi sehat dapat dimulai pada saat usia remaja. Seorang remaja harus disiapkan baik pengetahuan, sikap, dan perilakunya ke arah pencapaian reproduksi yang sehat (WHO, 1995). Ketika remaja putri sudah mulai mendapatkan menstruasi, hal utama yang harus diperhatikan adalah kebersihan pada saat menstruasi (personal hygiene). Hal ini dikarenakan pembuluh darah pada rahim sangat mudah terinfeksi ketika menstruasi karena kuman mudah masuk dan menimbulkan penyakit pada saluran reproduksi (Kusmiran, 2012). Kanker serviks adalah kanker yang terjadi pada daerah leher rahim, dan paling sering disebabkan karena perilaku yang tidak higienis pada saat menstruasi. Penelitian ini menggunakan desain cross sectional dengan sampel penelitian adalah siswi kelas 1, 2, dan 3 SMKN 8 Kota Bekasi yang diambil secara random sebanyak 240 siswi. Berdasarkan hasil penelitian yang telah dilakukan, maka diperoleh hasil dimana sebanyak $134(55,8 \%)$ siswi SMKN 8 Kota Bekasi memiliki perilaku kesehatan yang baik pada saat menstruasi. Dengan demikian dapat disimpulkan bahwa siswi SMKN 8 Kota Bekasi sudah memiliki kesadaran yang baik dalam berperilaku sehat untuk menjaga kesehatan selama menstruasi.
\end{abstract}

Kata kunci : Pengetahuan, Perilaku, Higiene, Menstruasi

Korespondensi: Noor Latifah A, .Program Studi Kesehatan MasyarakatFakultas Kedokteran dan Kesehatan Universitas Muhammadiyah Jakarta, Jl. KH. Ahmad Dahlan Cirendeu Ciputat Tangerang Selatan 15419, mobile: 082111999851, email: tiefa85@gmail.com 


\section{Pendahuluan}

Kesehatan reproduksi di kalangan remaja merupakan masalah yang sangat penting untuk mendapatkan perhatian. Kelompok remaja menjadi perhatian karena jumlah di kalangan remaja yang besar dan mempunyai risiko terhadap berbagai masalah kesehatan reproduksi. Seorang remaja harus disiapkan baik pengetahuan, sikap, dan perilakunya ke arah pencapaian reproduksi yang sehat (WHO, 1995).

Ketika remaja putri sudah mulai menstruasi, hal utama yang harus diperhatikan adalah kebersihan pada saat menstruasi (Personal Hygiene). Hal ini dikarenakan pembuluh darah pada rahim sangat mudah terinfeksi ketika menstruasi karena kuman mudah masuk dan menimbulkan penyakit pada saluran reproduksi (Kusmiran, 2012).

Keluhan pada organ reproduksi yang sering terjadi adalah Pruiritas vulvae yaitu ditandai dengan adanya sensasi gatal parah dari alat kelamin perempuan (Misery, 2010). Pruiritas vulvae disebabkan oleh jamur, bakteri, dan virus yang muncul karena buruknya Personal Hygiene dan Hygiene Menstruasi (44\%), karena alergen dan produk kewanitaan (30\%), serta karena kelainan patologik pada vulva $(26 \%)$.

Penyakit kanker merupakan salah satu penyebab utama kematian di seluruh dunia. Menurut data Global Burden Cancer (Globocan), International Agency for Research on Cancer (IARC), diketahui bahwa pada tahun 2012 terdapat
14.067.894 kasus baru kanker dan 8.201.575 kematian akibat kanker di seluruh dunia. Berdasarkan laporan yang diperoleh dari Globocan 2012 diperkirakan insidens kanker di Indonesia sebesar 134 per 100.000 penduduk. Sedangkan berdasarkan hasil wawancara Riskesdas 2013 didapatkan prevalensi penderita kanker di Indonesia sebesar 1,4 per 1000 penduduk. Penyakit kanker serviks dan payudara merupakan penyakit kanker dengan prevalensi tertinggi di Indonesia pada tahun 2013, yaitu kanker serviks sebesar 0,8 per 1000 penduduk dan kanker payudara sebesar 0,5 per 1000 penduduk.

Untuk menghindarkan dari sakit atau penyakit yang berkaitan dengan kesehatan reproduksi diperlukan personal hygiene yang baik. Skinner (1938) merumuskan bahwa perilaku terjadi melalui proses atau reaksi seseorang terhadap stimulus (rangsangan dari luar) terhadap organisme yang kemudian organisme tersebut merespon. Sejalan dengan batasan perilaku menurut Skinner, maka perilaku kesehatan (health behavior) adalah respon seseorang terhadap stimulus atau objek yang berkaitan dengan sehat/sakit (kesehatan), seperti lingkungan, makanan, minuman, pelayanan kesehatan. Perilaku kesehatan adalah semua aktivitas atau kegiatan seseorang baik yang diamati (observable) maupun yang tidak daoat diamati (unobservable) yang berkaitan dengan pemeliharaan dan peningkatan kesehatan. Pemeliharaan kesehatan mencakup mencegah atau melindungi diri dari penyakit dan masalah kesehatan lain, 
meningkatkan kesehatan dan mencari penyembuhan apabila sakit atau terkena masalah yang berhubungan dengan kesehatan (Notoatmodjo, 2012).

Personal Hygiene berasal dari bahasa, yaitu personal berarti perorangan dan hygiene adalah sehat. Kebersihan seseorang adalah suatu tindakan untuk memelihara kebersihan dan kesejahteraan fisik dan psikis (Laksmana, 2002).

\section{Metodologi}

Penelitian ini menggunakan desain studi cross sectional yaitu semua variabel diukur secara bersamaan dengan jenis penelitian kuantitatif dan menggunakan analisis deskriptif. Rancangan penelitian deskriptif bertujuan untuk menggambarkan perilaku remaja putri dalam menjaga higiene saat menstruasi pada siswi SMKN 8 Kota Bekasi. Penelitian dilakukan di SMKN 8 Kota Bekasi selama 3 bulan yaitu bulan Oktober - Desember 2015. Populasi dalam penelitian ini adalah seluruh siswi SMKN 8 Kota Bekasi dan sampel yang diambil adalah siswi kelas X, XI dan XII SMKN 8 Kota Bekasi yang berjumlah 240 orang.

Teknik pengambilan data dalam penelitian ini adalah kriteria sampel stratified random sampling. Pengambilan sampel dengan stratified random sampling dilakukan dengan cara mengidentifikasi karakteristik umum dari anggota populasi, kemudian menentukan strata atau lapisan dari jenis karakteristik unit-unit tersebut (Notoatmodjo, 2012). Dalam penelitian ini, penentuan strata didasarkan pada tingkatan kelas, yakni kelas $\mathrm{X}$, XI, dan XII. Setelah ditentukan stratanya barulah dari masing-masing strata dapat diambil sampel yang mewakili strata tersebut secara random atau acak.

Metode pengumpulan data dilakukan dengan menggunakan kuesioner. Penyebaran kuesioner dilakukan di SMKN 8 Kota Bekasi pada saat waktu istirahat sehingga tidak menggangu waktu jam mengajar. Kuesioner diberikan dan diisi oleh siswi SMKN 8 Kota Bekasi setelah diberikan penjelasan melalui informed consent.

Tahap-tahap pengolahan data meliputi editing data, coding data, entry data, dan cleaning data. Analisis data dilakukan dengan menggunakan program/aplikasi komputer yang dapat digunakan untuk mengolah statistik. Analisis data yang dilakukan berupa analisis univariat untuk mengetahui gambaran perilaku higiene menstruasi siswi SMKN 8 Kota Bekasi.

\section{Hasil}

Tabel 1. Karakteristik Siswi SMKN 8 Kota Bekasi

\begin{tabular}{lll}
\hline Variabel & $\mathbf{n}$ & $\mathbf{\%}$ \\
\hline Umur & & \\
$>16$ tahun & 107 & 80,8 \\
$\leq 16$ tahun & 133 & 19,2 \\
Total & $\mathbf{2 4 0}$ & $\mathbf{1 0 0}$ \\
Umur Menarche & & \\
$\geq 12$ tahun & 212 & 88,3 \\
$<12$ tahun & 28 & 11,7 \\
Total & $\mathbf{2 4 0}$ & $\mathbf{1 0 0}$ \\
Kelas Responden & \\
X & 80 & 33,3 \\
\hline
\end{tabular}




\begin{tabular}{lll}
\hline XI & 80 & 33,3 \\
XII & 80 & 33,3 \\
Total & $\mathbf{2 4 0}$ & $\mathbf{1 0 0}$ \\
\hline
\end{tabular}

Siswi SMKN 8 Kota Bekasi yang terlibat dalam penelitian yang berumur > 16 tahun sebanyak 107 siswi $(44,6 \%)$ dan sebagian besar siswi yang berumur $\leq 16$ tahun sebanyak 133 siswi $(55,4 \%)$.
Umur menarche yang dialami siswi SMKN 8 Kota Bekasi sebagian besar mengalami menarche pada usia $\geq 12$ tahun sebesar 88,3\% (212 siswi), sedangkan siswi yang mengalami menarche pada usia $>12$ tahun terdapat $11,7 \%$ (28 siswi). Responden yang terlibat dalam penelitian ini baik kelas X, XI, dan XII masingmasing berjumlah 80 orang.

\section{Tabel 2. Perilaku Higiene Menstruasi Menurut Kebiasaan Mandi Saat Menstruasi} Siswi SKMN 8 Kota Bekasi

\begin{tabular}{lllll}
\hline Variabel & \multicolumn{3}{c}{$\mathbf{n}(\%)$} \\
\cline { 2 - 5 } & $\begin{array}{l}\text { Tidak } \\
\text { Pernah }\end{array}$ & $\begin{array}{l}\text { Kadang- } \\
\text { kadang }\end{array}$ & Sering & Selalu \\
$\begin{array}{l}\text { Mandi dengan sabun mandi 2 kali sehari saat } \\
\text { menstruasi }\end{array}$ & $13(5,4 \%)$ & 20 & 207 \\
\hline
\end{tabular}

Berdasarkan hasil analisis univariat pada tabel 2, dapat disimpulkan bahwa sebagian besar yaitu 207 orang (86,2\%) selalu mandi dengan sabun 2 kali sehari pada saat menstruasi, sedangkan siswi yang sering terdapat 20 orang $(8,3 \%)$, dan kadang-kadang mandi sebanyak 13 orang $(5,4 \%)$.

Tabel 3. Perilaku Higiene Menstruasi Menurut Kebiasaan Mencuci Rambut Saat Menstruasi Siswi SMKN 8 Kota Bekasi

\begin{tabular}{lllll}
\hline Variabel & \multicolumn{3}{c}{ n (\%) } \\
\cline { 2 - 5 } & $\begin{array}{l}\text { Tidak } \\
\text { Pernah }\end{array}$ & $\begin{array}{l}\text { Kadang- } \\
\text { kadang }\end{array}$ & Sering & Selalu \\
$\begin{array}{l}\text { Mencuci rambut (keramas) 2 hari sekali saat } \\
\text { menstruasi }\end{array}$ & $72(30 \%)$ & $125(52,1 \%)$ & 25 & $18(7,5 \%)$ \\
$\begin{array}{l}\text { Tidak mencuci rambut (keramas) } \\
\text { menstruasi }\end{array}$ & selama & $87(36,2 \%)$ & $97(40,4 \%)$ & $(10,4 \%)$ \\
\hline
\end{tabular}

Tabel 3 di atas menunjukkan bahwa yang selalu mencuci rambut (keramas) 2 hari sekali selama menstruasi hanya 18 orang $(7,5 \%)$, dan tidak pernah mencuci rambut (keramas) 2 hari sekali yaitu 73 orang (30\%). Sedangkan yang tidak mencuci rambut (keramas) selama menstruasi terdapat 41 orang $(17,1 \%)$, dan sebagian besar kadang-kadang tidak mencuci rambut (keramas) sebanyak 97 orang $(40,4 \%)$. 
Tabel 4. Perilaku Higiene Menstruasi Menurut Kebiasaan Membersihkan Daerah Vagina Saat Menstruasi Siswi SMKN 8 Kota Bekasi

\begin{tabular}{|c|c|c|c|c|}
\hline \multirow[t]{3}{*}{ Variabel } & \multicolumn{4}{|c|}{ n (\%) } \\
\hline & Tidak & Kadang- & Sering & Selalu \\
\hline & Pernah & kadang & & \\
\hline $\begin{array}{l}\text { Membersihkan alat kelamin/kemaluan dengan air } \\
\text { bersih }\end{array}$ & & & $6(2,5 \%)$ & $\begin{array}{l}234 \\
(97,5 \%)\end{array}$ \\
\hline $\begin{array}{l}\text { Menggunakan sabun ketika membersihkan alat } \\
\text { kelamin/kemaluan }\end{array}$ & $\begin{array}{l}20 \\
(8,3 \%)\end{array}$ & $47(19,6 \%)$ & $\begin{array}{l}44 \\
(18,3 \%)\end{array}$ & $\begin{array}{l}129 \\
(53,8 \%)\end{array}$ \\
\hline $\begin{array}{l}\text { Membasuh alat kelamin/kemaluan dari arah } \\
\text { depan (vagina) ke belakang (anus) }\end{array}$ & $12(5 \%)$ & $27(11,2 \%)$ & $36(15 \%)$ & $\begin{array}{l}165 \\
(68,8 \%)\end{array}$ \\
\hline $\begin{array}{l}\text { Membersihkan alat kelamin/kemaluan, } \\
\text { mengeringkan dengan tisu atau handuk kering }\end{array}$ & $\begin{array}{l}16 \\
(6,7 \%)\end{array}$ & $66(27,5 \%)$ & $44(18,3 \%)$ & $\begin{array}{l}114 \\
(47,5 \%)\end{array}$ \\
\hline $\begin{array}{l}\text { Mencuci tangan dengan sabun setelah } \\
\text { membersihkan alat kelamin/kemaluan }\end{array}$ & $2(0,8 \%)$ & $20(8,3 \%)$ & $\begin{array}{l}25 \\
(10,4 \%)\end{array}$ & $\begin{array}{l}193 \\
(80,4 \%)\end{array}$ \\
\hline
\end{tabular}

Hasil analisis pada tabel 4 di atas menunjukkan bahwa sebagian besar siswi SMKN 8 Kota Bekasi sudah sangat baik dalam perilaku membersihkan daerah vagina pada saat menstruasi, hal ini dapat dilihat siswi yang membersihkan alat kelamin/kemaluan dengan air bersih terdapat 234 orang $(97,5 \%)$, tidak menggunakan sabun ketika membersihkan alat kelamin/kemaluan sebanyak 20 orang
$(8,3 \%)$, membasuh alat kelamin/kemaluan dari arah depan (vagina) ke arah belakang (anus) sebanyak 165 orang $(68,8 \%)$, membersihkan alat kelamin/kemaluan dan mengeringkan dengan tisu atau handuk kering sebanyak 114 orang $(47,5 \%)$, dan mencuci tangan dengan sabun setelah membersihkan alat kelamin/kemaluan sebanyak 193 orang $(80,4 \%)$.

Tabel 5. Perilaku Higiene Menstruasi Menurut Kebiasaan Menggunakan Celana Dalam Saat Menstruasi Siswi SMKN 8 Kota Bekasi

\begin{tabular}{lllll}
\hline Variabel & \multicolumn{3}{c}{ n (\%) } \\
\cline { 2 - 5 } & $\begin{array}{l}\text { Tidak } \\
\text { Pernah }\end{array}$ & $\begin{array}{l}\text { Kadang- } \\
\text { kadang }\end{array}$ & Sering & Selalu \\
$\begin{array}{l}\text { Mengganti celana dalam min. 2 kali sehari } \\
\text { saat menstruasi }\end{array}$ & & & 71 & 92 \\
$\begin{array}{l}\text { Memakai celana dalam } \\
\text { keringat ketika menstruasi }\end{array}$ & $68(28,3 \%)$ & $(29,6 \%)$ & $(38,3 \%)$ \\
$\begin{array}{l}\text { Tidak menggunakan celana dalam yang ketat } \\
\text { saat menstruasi }\end{array}$ & $31(12,9 \%)$ & $75(31,2 \%)$ & 38 & $96(40 \%)$ \\
$\begin{array}{l}\text { Segera mengganti celana dalam yang terkena } \\
\text { darah saat menstruasi }\end{array}$ & & & $(15,8 \%)$ & \\
\hline
\end{tabular}


Berdasarkan tabel 5 dapat (38,3\%), memakai celana dalam yang disimpulkan bahwa sebagian besar siswi sudah memiliki perilaku higiene menstruasi yang baik tentang kebiasaan menggunakan celana dalam selama menstruasi yaitu mengganti celana dalam minimal 2 kali sehari sebanyak 92 orang menyerap keringat sebanyak 114 orang $(47,5 \%)$, tidak menggunakan celana dalam yang ketat sebanyak 96 orang (40\%), dan segera mengganti celana dalam yang terkena darah saat menstruasi sebanyak 210 orang $(87,5 \%)$.

Tabel 6. Perilaku Higiene Menstruasi Menurut Kebiasaan Menggunakan/Mengganti Pembalut Saat Menstruasi Siswi SMKN 8 Kota Bekasi

\begin{tabular}{|c|c|c|c|c|}
\hline \multirow[t]{2}{*}{ Variabel } & \multicolumn{4}{|c|}{ n (\%) } \\
\hline & $\begin{array}{l}\text { Tidak } \\
\text { Pernah }\end{array}$ & $\begin{array}{l}\text { Kadang- } \\
\text { kadang }\end{array}$ & Sering & Selalu \\
\hline Mengganti pembalut setiap 4 jam sekali & $28(11,7 \%)$ & $112(46,7 \%)$ & $\begin{array}{l}49 \\
(20,4 \%)\end{array}$ & $\begin{array}{l}51 \\
(21,2 \%)\end{array}$ \\
\hline $\begin{array}{l}\text { Mengganti pembalut setelah penuh dengan } \\
\text { darah }\end{array}$ & $7(2,9 \%)$ & $23(9,6 \%)$ & $\begin{array}{l}32 \\
(13,3 \%)\end{array}$ & $\begin{array}{l}178 \\
(74,2 \%)\end{array}$ \\
\hline $\begin{array}{l}\text { Mengganti pembalut ketika ada gumpalan } \\
\text { darah di pembalut }\end{array}$ & $7(2,9 \%)$ & $111(46,2 \%)$ & $\begin{array}{l}51 \\
(21,2 \%)\end{array}$ & $\begin{array}{l}71 \\
(29,6 \%)\end{array}$ \\
\hline $\begin{array}{l}\text { Tidak mengganti pembalut setiap kali buang air } \\
\text { kecil/buang air besar }\end{array}$ & $36(15 \%)$ & $138(57,5 \%)$ & $\begin{array}{l}30 \\
(12,5 \%)\end{array}$ & $36(15 \%)$ \\
\hline $\begin{array}{l}\text { Membungkus pembalut dengan kertas/plastik } \\
\text { sebelum dibuang ke tempat sampah }\end{array}$ & & $4(1,7 \%)$ & $8(3,3 \%)$ & $\begin{array}{l}228 \\
(95 \%)\end{array}$ \\
\hline $\begin{array}{l}\text { Mencuci tangan dengan sabun sebelum dan } \\
\text { sesudah mengganti pembalut }\end{array}$ & $3(1,2 \%)$ & $20(8,3 \%)$ & $\begin{array}{l}18 \\
(7,5 \%)\end{array}$ & $\begin{array}{l}199 \\
(82,9 \%)\end{array}$ \\
\hline
\end{tabular}

Perilaku siswi terhadap penggunaan/penggantian pembalut selama menstruasi berdasarkan pada tabel 6 menunjukkan bahwa siswi yang selalu mengganti pembalutnya setiap 4 jam sekali hanya terdapat 51 orang $(21,2 \%)$, dan sebagian besar kadang-kadang mengganti pembalutnya setiap 4 jam sekali $(46,7 \%)$. Sebagian besar siswi selalu mengganti pembalutnya setelah penuh dengan darah sebanyak 178 orang $(74,2 \%)$. Siswi yang selalu mengganti pembalutnya ketika ada gumpalan darah di pembalut sebanyak 71 orang $(29,6 \%)$. Terdapat 36 orang (15\%) yang tidak mengganti pembalut setelah buang air kecil/buang air besar. Sebanyak 228 orang $(95 \%)$ selalu membungkus pembalut dengan kertas/plastik sebelum dibuang ke tempat sampah. Terdapat 199 orang $(82,9 \%)$ selalu mencuci tangan dengan sabun sebelum dan sesudah mengganti pembalut. 


\section{Diskusi}

\section{Karakteristik Responden}

a. Umur

Siswi SMKN 8 Kota Bekasi yang terlibat dalam penelitian memiliki umur $>16$ tahun terdapat sebanyak 107 siswi $(44,6 \%)$ dan sebagian besar siswi memiliki umur $\leq 16$ tahun yaitu sebanyak 133 siswi $(55,4 \%)$.

Berdasarkan jumlah siswi yang terlibat dalam penelitian lebih banyak pada siswi yang berumur $\leq$ 16 tahun, maka menurut Bobak, Lowdermik \& Jensen (2005) dapat disimpulkan bahwa siswi yang terlibat dalam penelitian merupakan remaja tahap menengah yaitu 1 orang $(0,4 \%)$ berumur 14 tahun, 45 orang $(18,8 \%)$ berumur 15 tahun, dan 87 orang $(36,2 \%)$ berumur 16 tahun.

Usia merupakan faktor yang mewakili tingkat kematangan seorang siswa (Sunarto dan Hartono, 2008). Usia remaja merupakan usia yang sangat rentan mempunyai resiko terhadap berbagai masalah kesehatan reproduksi. Seorang remaja harus disiapkan baik pengetahuan, sikap, dan perilakunya ke arah pencapaian reproduksi yang sehat (WHO, 1995).

\section{b. Usia Menarche}

$$
\begin{array}{r}
\text { Rata-rata usia menarche } \\
\text { siswi SMKN } 8 \text { Kota Bekasi }
\end{array}
$$

berusia $\geq 12$ tahun sebanyak 212 orang (88,3\%), yaitu usia 12 tahun (79 orang), 13 tahun (85 orang), 14 tahun (42 orang), 15 tahun (5 orang), 16 tahun (1 orang). Usia menarche pada siswi tersebut berada dalam rentang usia $10-19$ tahun yang merupakan periode pematangan organ reproduksi manusia. Sedangkan masa remaja awal dan masa pubertas disertai dengan perubahan fisik, salah cirinya pada remaja putri adalah terjadi menarche berada pada rentang usia 10 - 12 tahun (Pinem, 2009).

Menurut Behrman (2000) dan Soetjiningsih (2007) menjelaskan bahwa rata-rata usia menarche adalah usia 10,5 - 15,5 tahun. Rata-rata usia mendapatkan menstruasi pertama (menarche) pada usia 10,61 tahun, sebagian besar berusia 10 tahun $(30,5 \%)$ dan 11 tahun (47,5\%) (Imarotul Fitriyah, 2014). Sedangkan hasil Riset Kesehatan Dasar (Riskesdas, 2010), umumnya remaja putri mengalami menarche pada usia 9 -12 tahun.

\section{Perilaku Higiene Menstruasi}

Skinner berpendapat bahwa perilaku kesehatan merupakan semua aktivitas seseorang yang berkaitan dengan pemeliharaan dan peningkatan kesehatan. Perilaku higiene menstruasi merupakan upaya/tindakan untuk menghindari masalah pada 
organ reproduksi (Notoatmodjo, 2005).

Personal hygiene pada saat menstruasi merupakan kebersihan perorangan dalam usaha memelihara, mempertahankan dan memperbaiki kebersihan dan kesehatan seseorang untuk kesejahteraan fisik maupun psikologis melalui implementasi tindakan hygiene yang dilakukan selama menstruasi (Manuaba, 2008; Patricia, 2005; Tarwoto, 2010)

\section{Perilaku Personal hygiene} selama menstruasi merupakan sebuah proses yang dipelajari secara bertahap karena secara perlahan individu mulai menyadari dampak negatif atau positif terhadap perilaku yang terkait dengan keadaan menstruasi (Indriastuti, 2009).

Dalam penelitian ini diperoleh bahwa responden yang sudah memiliki perilaku baik dalam higiene menstruasi sebanyak 134 orang $(55,8 \%)$ dari 240 responden. Perilaku baik yang dimiliki oleh responden tersebut didukung oleh perilaku sehat yang dilakukan selama menstruasi diantaranya mandi dengan sabun mandi 2 kali sehari $(86,2 \%)$, aktivitas mandi selama mentruasi dimaksudkan untuk menjaga kesegaran badan dan bebas dari bau badan akibat dari produksi keringat yang berlebih selama menstruasi (Kusmiran, 2012). Hal ini juga sesuai dengan penelitian yang dilakukan oleh Lawan, Yusuf, \& Musa (2012) yang menjelaskan bahwa remaja putri menambah frekuensi mandinya saat menstruasi sebanyak 3 -4 kali sehari.

Perilaku higiene menstruasi selanjutnya berkaitan dengan aktivitas membersihkan area vagina yaitu selalu membersihkan alat kelamin/kemaluan dengan air bersih (97,5\%). Imarotul Fitriyah (2014) dalam penelitiannya juga menyebutkan bahwa $92,3 \%$ responden membersihkan alat kelamin dengan air bersih. Membersihkan alat kelamin/kemaluan dengan air bersih tidak hanya dilakukan pada saat menstruasi saja, tetapi juga dilakukan selain dari saat menstruasi. Sebaiknya membersihkan alat kelamin/kemaluan cukup dibersihkan dengan air hangat, tanpa menggunakan sabun khusus untuk membersihkan vagina, karena pada vagina terdapat kuman Doderlin yang berfungsi memproduksi asam yang dapat mencegah bakteri masuk ke dalam vagina dan menyebabkan infeksi. Tetapi pada penelitian ini sebagian besar responden selalu menggunakan sabun ketika membersihkan alat kelamin/kemaluan $(53,8 \%)$, dan yang tidak 
menggunakan sabun hanya sebanyak 20 orang $(8,3 \%)$. Selalu membasuh alat kelamin/kemaluan dari arah depan (vagina) ke arah belakang (anus) (68,8\%), dikarenakan untuk menghindarkan bakteri yang ada di area anus tidak terbawa masuk ke dalam vagina yang beresiko dapat menimbulkan infeksi. Setelah membersihkan alat kelamin/kemaluan selalu mengeringkan dengan tisu atau handuk kering (47,5\%), dimaksudkan supaya vagian tidak lembab dan mencegah bakteri yeng merugikan tumbuh di daerah kemaluan (Pudiastuti, 2012). Aktivitas mencuci tangan dengan sabun setelah membersihkan alat kelamin/kemaluan $(80,4 \%)$, perilaku mencuci tangan dengan sabun setelah membersihkan area kelamin/kemaluan diperlukan dengan tujuan menghindarkan bakteri/kuman-kuman masuk ke dalam tubuh melalui mulut karena bagian tubuh berupa tangan sering digunakan untuk aktivitas makan dan minum.

Perilaku selalu mengganti celana dalam 2 kali sehari saat menstruasi $(38,3 \%)$, selalu memakai celana dalam yang menyerap keringat ketika menstruasi $(47,5 \%)$, segera mengganti celana dalam yang terkena darah saat menstruasi $(87,5 \%)$.
Sedangkan pada penelitian yang dilakukan oleh Imarotul Fitriyah (2014) menghasilkan penelitian berupa mengganti celana dalam 2 kali sehari $(71,2 \%)$, mengganti celana dalam saat terkena darah menstruasi $(88,1 \%)$, dengan mengganti celana dalam secara rutin minimal 2 kali sehari atau segera mengganti celana dalam ketika terkena darah, hal ini dilakukan untuk mencegah vagina dari kelembaan yang berlebihan sehingga dapat menghindari bakteri merugikan tumbuh di area vagina dan menggunakan celana dalam yang tidak bersih akan mengakibatkan infeksi pada area vagina (Kusmiran, 2012).

Perilaku kadang-kadang mengganti pembalut setiap 4 jam sekali sebesar 46,\%. Perilaku kadangkadang mengganti pembalut setiap 4 jam sekali kemungkinan dikarenakan jumlah darah haid yang keluar, semakin banyak jumlah darah yang keluar semakin sering mengganti pembalut dalam seharinya, hal ini dapat dilihat dari perilaku selalu mengganti pembalut setelah penuh dengan darah $(74,2 \%)$. Ketika darah sudah memenuhi pembalut bertujuan untuk menghindari kelembaban pada area vagina, dikarenakan jika area vagina lembab akan memudahkan 
mikroorganisme dan jamur tumbuh dan mengakibatkan area vagina menjadi gatal dan berbau. Selain itu, mengganti pembalut tidak boleh dilakukan lebih dari 6 jam, dikarenakan pembalut akan menyimpan bakteri jika tidak diganti dengan pembalut yang baru dalam waktu lama. Lee et al (2006) dalam peneltiannya menjelaskan bahwa dari seluruh responden remaja putri di Malaysia terdapat $\quad 70,8 \%$ menggunakan $\leq 4$ pembalut per hari dikarenakan jumlah darah haid yang keluar sedikit, menggunakan 2 pembalut per hari dalam satu pemakaian ketika jumlah darah yang keluar sangat banyak terdapat sebanyak $17,6 \%$, dan menggunakan 5 - 10 pembalut per hari sebanyak $11,1 \%$ dikarenakan jumlah darahnya sedang.

Perilaku selalu membungkus pembalut dengan kertas/plastik sebelum dibuang ke tempat sampah (95\%). Hasil penelitian ini sesuai dengan penelitian yang dilakukan oleh Imarotul Fitriyah (2014) yang mengatakan bahwa 94,9\% responden membungkus pembalut bekas pakai sebelum dibuang. Selain itu Thakre (2011) mengemukakan hasil penelitian yang sama bahwa responden sebelum membuang pembalut bekas pakai, pembalut dibungkus dengan kertas terlebih dahulu, dan kemudian membuang pembalut ke dalam kategori limbah padat atau membakarnya. Perilaku selalu mencuci tangan dengan sabun sebelum dan sesudah mengganti pembalut $(82,9 \%)$, perilaku ini dilakukan untuk menghindari kuman atau bakteri masuk ke dalam tubuh memalui mulut karena seringnya aktivitas tangan berkaitan dengan makan dan minum.

Selain itu, Suryati (2012) dalam penelitian yang telah dilakukannya pada remaja putri SMPN 2 Depok diperoleh 143 orang (76,9\%) dari 186 responden mempunyai perilaku yang baik dalam menjaga kebersihan pada saat menstruasi, hal ini didukung dengan frekuensi mengganti pembalut pada saat menstruasi sedikit yaitu sebesar 68,3\% dan hal-hal yang perlu diperhatikan saat menstruasi sebesar $96,8 \%$, serta mengetahui akibat yang ditimbulkan jika tidak menjaga kebersihan saat menstruasi.

Secara keseluruhan, dapat disimpulkan bahwa perilaku siswi SMKN 08 Kota Bekasi sudah baik $(55,8 \%)$. Untuk membentuk perilaku yang lebih baik lagi dalam higiene menstruasi perlu didukung oleh 
pengetahuan yang baik mengenai higine menstruasi.

Teori Green mengemukakan bahwa perilaku seseorang dipengaruhi oleh faktor predisposisi yang salah satunya adalah pengetahuan. Pengetahuan seseorang baik individu atau masyarakat akan berperilaku sesuai dengan pengetahuan yang dimilikinya.

Pengetahuan atau kognitif merupakan domain yang sangat penting untuk terbentuknya tindakan seseorang (overt behaviour) karena dari pengalaman dan penelitian ternyata perilaku didasarkan oleh pengetahuan akan lebih langgeng daripada perilaku yang tidak didasari oleh pengetahuan (Notoatmodjo, 2011).

\section{Kesimpulan}

Dari seluruh responden yang diteliti, diketahui bahwa sebagian responden mengalami menarche pada usia $\geq 12$ tahun $(88,3 \%)$. Sedangkan dalam perilaku higiene menstruasi yang baik dapat diketahui dengan perilaku responden berupa : $86,2 \%$ selalu mandi dengan sabun 2 kali sehari pada saat menstruasi, 97,5\% selalu membersihkan

alat kelamin/kemaluan dengan air bersih, $68,8 \%$ selalu membasuh alat kelamin/kemaluan dari arah depan (vagina) ke arah belakang (anus), 47,5\% selalu membersihkan kelamin/kemaluan dan mengeringkan dengan tisu atau handuk kering, 80,4\% selalu mencuci tangan dengan sabun setelah membersihkan alat kelamin/kemaluan, $\quad 38,3 \% \quad$ selalu mengganti celana dalam minimal 2 kali sehari, $47,5 \%$ selalu memakai celana dalam yang menyerap keringat, $40 \%$ tidak menggunakan celana dalam yang ketat, $87,5 \%$ segera mengganti celana dalam yang terkena darah saat menstruasi, $74,2 \%$ selalu mengganti pembalutnya setelah penuh dengan darah, $95 \%$ selalu membungkus pembalut dengan kertas/plastik sebelum dibuang ke tempat sampah, dan terdapat $82,9 \%$ selalu mencuci tangan dengan sabun sebelum dan sesudah mengganti pembalut.

Dengan demikian, perilaku siswi SMKN 8 Kota Bekasi secara keseluruhan dalam higiene menstruasi dinilai sudah baik $(55,8 \%)$. Untuk membentuk perilaku yang lebih baik lagi dalam higiene menstruasi perlu didukung oleh pengetahuan yang baik mengenai higine menstruasi. Pengetahuan atau kognitif merupakan domain yang sangat penting untuk terbentuknya tindakan seseorang (overt behaviour) karena dari pengalaman dan penelitian ternyata perilaku didasarkan oleh pengetahuan akan lebih langgeng daripada perilaku yang tidak didasari oleh pengetahuan (Notoatmodjo, 2011).

\section{Saran}

Perilaku yang baik tentu didukung oleh pengetahuan yang baik mengenai higiene menstruasi. Pengetahuan yang semakin baik akan membuat seseorang 
berperilaku semakin baik dalam higiene menstruasi. Perilaku dan pengetahuan mengenai higiene menstruasi yang baik akan dapat mencegah seseorang dari penyakit yang berbahaya seperti kanker serviks di mana pada tahun 2013 menempati posisi tertinggi di Indonesia (0,8 per 1000 penduduk).

Pengetahuan mengenai higiene menstruasi perlu ditingkatkan pada siswi SMKN 8 Kota Bekasi untuk mendukung perilaku yang baik dalam higiene menstruasi, dikarenakan masih terdapatnya siswi SMKN 8 yang memiliki pengetahuan sedang dan rendah memiliki perilaku higiene menstruasi yang kurang baik. Peran serta sekolah sangat dibutuhkan untuk memberikan pengetahuan tentang higiene menstruasi kepada siswinya dapat berupa pengadaan seminar, penyuluhan, dan diskusi kesehatan yang rutin diadakan di sekolah.

Dilakukan penelitian lanjutan untuk melihat hubungan antara pengetahuan tentang higiene menstruasi dengan perilaku higiene menstruasi guna untuk mendukung hasil penelitian ini lebih lanjut.

\section{Daftar Pustaka}

1. Fitriyah, Imarotul. Gambaran Perilaku Higiene Menstruasi pada Remaja Putri di Sekolah Dasar Negeri Di Wilayah Kerja Puskesmas Pisangan. Skripsi, Universitas Islam Negeri Syarif Hidayatullah Jakarta. 2014.

2. Indriastuti, P. Hubungan antara Pengetahuan Kesehatan Reproduksi dengan Perilaku Hygienis Remaja Putri pada saat Menstruasi. Thesis, Universitas Muhammadiyah Surakarta. 2009.

3. Kusmiran, Eny. Kesehatan Reproduksi Remaja dan Wanita. Jakarta: Salemba. 2012.

4. Lawan, Nafisa Wali Yusuf, dan Aisha Bala Musa. Menstruation and Menstrual Higiene among Adolescent School Girls in Kano, Northwestern Nigeria. Afr J. Reprod. Health 2010; 14(3j:201-207). Dari http://web.ebscohost.com/ehost/pdfvi ewer/pdfviewer?sid=1d12f577-c9594394-bdf8-

5f4c592e3e87\%40sessionmgr4\&vid $=1 \&$ hid $=23$ diakses tanggal 2 Oktober 2013.

5. Lee, et al. Menstruation among Adolescent Girls in Malaysia: a Cross-Sectional School Survey. Singapore Med J 2006; 47(10): 869. Dari

http://www.ncbi.nlm.nih.gov/pubmed /16990962 diakses tanggal 9 Oktober 2013.

6. Lestari, Prasetya. Hubungan Pengetahuan Menstruasi dan Komunikasi Teman Sebaya dengan Personal Hygiene selama Menstruasi pada Siswi SMA. Surakarta. 2014.

7. Manuaba, I. Ilmu Kebidanan, Penyakit Kandungan \& Keluarga Berencana untuk Pendidikan Bidan, Jakarta: EGC. 2008. 
8. Misery, Laurent dan Sonja Stander. Pruritus. London: Springer. 2010.

9. Notoatmodjo, Soekidjo. Kesehatan Masyarakat. Jakarta. Rineka Cipta. 2011.

10. , Soekidjo. Kesehatan Masyarakat Ilmu dan Seni. Jakarta. Rineka Cipta. 2011.

11. Patricia, A. Buku Ajar Fundamental Keperawatan Konsep Edisi 4. Jakarta: EGC. 2005.

12. Suryati, B. Perilaku Kebersihan Remaja saat Menstruasi. Jurnal Health Quality. Vol. 3 No. 1, Np. 2012. Pp: 54 http://stikesbpi.ac.id/media/file/897084724jurnal _Perilaku_Kebersihan_Remaja_saat_
Menstruasi.pdf. Diakses pada tanggal 7 Januari 2014.

13. Tarwoto dan Wartonah. Kebutuhan Dasar Manusia dan Proses Keperawatan. Jakarta: Salemba Medika. 2010.

14. Thakre, Subhash B et al. Menstruak Hygiene: Knowledge and Practice among Adolescent School Girls of Saoner, Nagpur District. Journal of Clinical and Diagnostic Research. 2011 October, Vol.5(5): 1027-1033.

15. http://www.wsscc.org/sites/default/fil es/publications/thakreetal_mhknowls gepracticenagpur_india_2011.pdf diakses tanggal 12 Oktober 2013 